\title{
Framing the Primordial: Islamic Heritage and Saudi Arabia
}

\section{Ömer Can Aksoy}

\begin{abstract}
This chapter addresses the concept of "Islamic Heritage" from the perspective of the theological questions on the primordial status of Islam, considering the interpretation of the concept of fitra in Muslim scholarship, particularly those raised by Salafi scholars. I argue that it is atypical to frame any period of the past as Islamic within the setting of Muslim World, since Islam regards itself as the primordial faith. I refer to two case studies from Saudi Arabia where the Muhammad ibn Abd-al-Wahhab's movement has had a significant impact on both an official historiography and the heritage management of the Kingdom: Saudi Arabian museums and the Hejaz Railway, which demonstrate the ways in which different epochs of the past in Saudi Arabia are made to conform to a specific Islamic timeline.
\end{abstract}

Keywords Islamic Archaeology · rock art · museums · the Hejaz Railway · Ottoman · Saudi Arabia

\section{INTRODUCTION}

This chapter scrutinizes the concept of "Islamic heritage" from the perspective of theological questions on the primordial status of Islam. My argument rests on the assertion that it is atypical to frame any period of the past as

Ö.C. Aksoy $(\bowtie)$

UCL Qatar, Doha, Qatar

(C) The Author(s) 2017

T. Rico (ed.), The Making of Islamic Heritage, Heritage Studies in the

Muslim World, DOI 10.1007/978-981-10-4071-9_5 
Islamic within the context of the Muslim world, since Islam regards itself as the primordial faith. In order to demonstrate this claim, I focus on case studies from Saudi Arabia where Muhammad ibn Abd-al-Wahhab's movement has a considerable foothold in both an official historiography and the heritage management of the Kingdom. Consequently, in this chapter I revisit the interpretations concerning the concept of fitra (the primordial state of humankind) in Muslim scholarship, particularly those raised by Salafi scholars. Under the light of this theological background, this chapter presents fieldwork in Saudi Arabian museums and on the Hejaz Railway. ${ }^{1}$ Both of these case studies illustrate the ways that different periods of the past in Saudi Arabia are made to conform to a specific Islamic timeline.

In the academic sense, the word "Islamic" is a qualifier that can be applied to describe a wide range of disciplinary foci, including but not limited to architecture, archaeology, and heritage (Grube 1978; Insoll 1999, 2007; Milwright 2010, 11). However, it is worth noting that, generally speaking, the disciplines of Islamic archaeology and Islamic architecture are dominated by a secular viewpoint; therefore, questions about the origin and scope of Islam have largely been avoided in these disciplinary frameworks. Rather, various "key points" have been formalized in order to identify the material culture of Islam in archaeological and architectural contexts (see Grube 1978; Milwright 2010, 125-158; Petersen 1996, 2014). For instance, Petersen (2014) counts mosques, the hajj routes, shrines, and the halal diet as areas of research that are of particular significance to an understanding of Islam. In contrast, Insoll $(1999,2007)$ casts a more inclusive role for Islamic archaeology in consideration of the potential influence of Islam on all aspects of Muslims' lives. He suggests that an archaeology of Islam "must be regarded as a complete system," a "residue" of individuals and beliefs spread over time and space (Insoll 1999, 228). Such a research approach can cover the cultural diversity and human agency in Muslim communities of the past in a more holistic way, but it has nonetheless failed to address a holistic manifestation of faith in that it rules out the concepts of fitra, qadar (pre-destination), and dalal (going astray) in Islam. Muslim scholars have fiercely debated the relationship between these concepts for centuries. These arguments rest particularly on the question of whether divine knowledge predetermines human choice on matters of faith and beliefs (Holtzman 2010, 176-177). I believe these arguments are vital to comprehend the approaches of Muslim polities and individuals to the past, the practice of archaeology, and heritage management. The naming of the 
Nabatean settlement of Hegra (al-Hijr) as Mada'in Saleh, or cities of Saleh in reference to Prophet Saleh, is case in point (Nehmé 2007, 12). The verses about al-Hijr and Prophet Saleh in the Quran point out a case where a community (the Thamud) acted against the will of God (by slaying of she-camel), denied the messages of his messenger (Prophet Saleh), and faced the wrath of God as result of its act (see al-A'raf: 7379; al-Hijr: 80). Eventually, Hegra came to be viewed as an unpleasant area in Muslim tradition and the present-day surrounding community (Alrawaibah 2013, 149). A comprehensive definition of these concepts is beyond the scope of this example and the present chapter (see Holtzman 2010, 167-172); I will therefore focus on the concept of fitra since, I suggest, it plays a key role in the heritage management of Saudi Arabia.

\section{Primordial Time}

The notion of fitra in the Qur'an (Surat al-Rum, verse 30) and various hadiths of Bukhari and Muslim enrich as well as complicate our understanding of the sense of the past in Islam and among Muslims. There are several meanings attested to the term fitra by a number of scholars: the state of Islam (Ibn Taymiyya), the natural union with Allah (Ibn Abd alWahhab), and the state of perfection (Ibn Abd al-Barr). Two conflicting views can be drawn from these explanations. One of these suggests that the concept of fitra addresses the belief that the sense of Allah and Islam exists in all human beings at the time of their birth. This view was mainly adopted by Ibn Taymiyya and Ibn Abd al-Wahhab. They considered that the inclination toward any other beliefs in a lifetime is a diversion from human nature (Ibn Abd Al-Wahhab 2010, 43-92; Holtzman 2010, 167181; Hökelekli 1996, 47-48; Noyes 2013). The second view, which was raised by Ibn Abd al-Barr, puts forward the belief that all human beings are born in a neutral state, but with the potential to embrace Islam (Adang 2000, 408; Hökelekli 1996, 47-48).

Given the tenor of these interpretations, all pasts, including one's personal past, can be labeled as Islamic. The concept of fitra raises the question of whether to apply the term "Islamic heritage" to a period starting from $610 \mathrm{AD}$ until this day or to refer to a timeline that reiterates this primordial principle. This question does not pose a major problem from the outlook of Islamic archaeology, since scholars draw lines in accordance with each period and type of material culture in their studies (Milwright 2010, 11-30; Petersen 2014, 6275). However, this is not 
merely a theological question that has implications for chronologies; it also directly addresses the complex relationship between present-day societies and the tangible and intangible heritage that is associated with Islam. Saudi Arabia exemplifies this challenge, where Ibn Abd al-Wahhab's ideals affect the official historiography of the Kingdom. In this discussion, I will address two case studies from Saudi Arabia: The first includes three museums, Tayma, al-Ula, and the National Museum, and the second examines the Hejaz Railway. These sites address two aspects associated with the categorization and problematization of the idea of an Islamic heritage and Islamic past. An examination of museums is aimed at the question of representation of pre- and post-seventh-century $\mathrm{AD}$ epochs, considering national and local museum narratives. These museums present Saudi Arabia's heritage in a primordial timeline that makes reference to the Qur'an, the official historiography, and to archaeological studies. An examination of the Hejaz Railway is aimed at scrutinizing the different meanings and labels that are attached to the Ottoman past by local populations and government bodies. In this case study, the concepts of Islamic heritage and Islamic past are critiqued through an analysis of one of the features that is presented as a defining element of the Railway: a hajj route (see Petersen 2014). The formation processes of the stations of this early-twentieth-century hajj route illustrate precisely how the terms "Islamic heritage" and "Islamic past" are loosely defined. My motivation for citing these two seemingly far-flung case studies is twofold. First, to illustrate that the concepts of "Islamic archaeology," "Islamic heritage," and "Islamic past" are in a state of flux. Though this has been argued by Millwright $(2009,2010)$ in relation to archaeological theory and methodologies and textual histories, this chapter offers a theological and historical basis for this argument. Second, to highlight the potential drawbacks in any attempt to contextualize the terms "Islamic archaeology," "Islamic heritage," and "Islamic past."

\section{Museums of Messages}

Saudi Arabia curates its history with respect to the Qur'an, traditional Muslim historiography, and archaeological research. This complex justification for curation manifests itself clearly in the designed spaces of the National Museum and the local museums of the Kingdom, creating a recognizable style. For example, the museums in al-Ula and Tayma are almost identical in terms of architecture and exhibition design. There are 
only differences between them regarding the contexts of the objects that are on display (see Michael Rice \& Company Ltd. 1984). Boards, inscribed with Surat al-Rum's verse 9, are placed in the reception halls of these museums. The al-Ula and Tayma museums are not exceptional examples, as the Saudi Commission for Tourism and National Heritage $(\mathrm{SCTH})^{2}$ Museums Directory website stresses that Qur'anic verses are also on display in the entrance halls of Tabuk, Hail, and al Baha museums, though their verse numbers are not specified (SCTH 2014). These verses are described as "Qur'anic verses describing religion's relationship with archaeological studies" (SCTH 2014). That is to say, these boards contextualize archaeology and the museums in the realm of Islam-a vital prerequisite within the theocratic framework of the Saudi state and ulama (Commins 2006; The Basic Law of Governance 1992).

A closer look at verse 9 of the Surat al-Rum on the walls of al-Ula and Tayma museums deepens our understanding of the relationship between archaeology, Islam, and museums in Saudi Arabia:

Have they not travelled in the land and seen what resulted in the end for those before them? They were more powerful than these, and they dug the earth, and built upon it more these have built. Messengers of their own came to them with clear proofs. God did not wrong them, but they did wrong themselves. (Surat al-Rum, verse 9: translation on the Tayma Museum's Board 2014)

Surat al-Rum plays a significant role in the debates on the concept of fitra among Muslim scholars, including Ibn Taymiyyah and Ibn Abd al-Barr (Hökelekli 1996, 47-48). In the view of these discussions, I suggest that the verse 9 boards in the entrance halls summon the visitors to question their own fitra while viewing the objects on display. Put in stark terms, these are didactic museums-museums of messages.

The National Museum highlights this primordial timeline to its visitors in greater detail than the Al-Ula and Tayma museums (see Okruhlik 2004, 213-215). The museum lies in the middle section of the King Abdul-Aziz Historical Center in Riyadh, which was founded to be "a cultural and civilization center highlighting the prominent history of the Arabian Peninsula and its historical message of disseminating Islam" (Introduction, The National Museum 2015). Both the architectural vocabulary and the narratives of the museum draw a "framework of geographical and cultural unity" (Introduction, The National Museum 2015) in order to create "a sense of continuity and dignity for all Saudis" 
(Boddy 1999, 24). Artifacts, architectural finds, and replicas in this museum are displayed in seven sequential exhibition halls organized under the following themes:

1. "Man and Universe": origins of the Universe, geology, fossils, and Neolithic artefacts.

2. "The Arab Kingdoms": Arabian scripts and late Bronze Age-third century AD polities.

3. "Al-Jahiliyyah (Pre-Islamic) Era": caravan routes, markets, Arab poetry, and oasis settlements.

4. "The Prophet's Mission": the life of Prophet Muhammad, his lineage, and major events from his birth in Mecca until the hijra (the migration of the Prophet and his followers from Mecca to Medina) in $622 \mathrm{AD}$.

5. "Islam and the Arabian Peninsula": Umayyad-Abbasid, Mamluk, and Ottoman era finds, and Mecca.

6. "The First Saudi State and the Second Saudi State": the lives of Imam Muhammad bin Saud and Sheikh Mohammed bin Abdul Wahhab, and the history of Dirriyah.

7. "Unification of the Kingdom": the Unification War and King Abdulaziz's life.

8. "Hajj and the Two Holy Mosques": the role of previous polities in preserving the hajj rituals, historical hajj routes, the development of Mecca and Medina, and the role of the Saudi state in providing services to pilgrims.

The Qur'an has a significant role in the historical narratives of the National Museum in line with what is observed in the aforementioned local museum examples. The first thing that visitors encounter in the "Man and Universe" hall is a video installation featuring the universe under the title, "The Glory of His Creation." The board underneath the installation cites Al-A'raf, verse 54:

Your Guardian-Lord is Allah, who created the heavens and the earth in six Days, and is firmly established on the Throne (of authority): He draweth the night as a veil o'er the day, each seeking the other in rapid succession: $\mathrm{He}$ created the sun, the moon, and the stars, (all) governed by laws under his Command. Is it not His to create and to govern? Blessed be Allah the Cherisher and Sustainer of the Worlds! (Yusuf 2000, 120, [sic]) 
The reason behind this installation becomes obvious when we take a closer look at the SCTH's webpage on the National Museum: "This hall reviews the scientific phenomena which shows the greatness of the Almighty Creator in the creation of the universe" (SCTH 2011). The impact of the Qur'an and the hadiths is less apparent in the "Arab Kingdoms" hall; the information presented in this hall is heavily reliant on the past three decade's excavation and survey results from northwestern Arabia. Nevertheless, a reference to the Surat al-Hijr is made in the museum guidebook on the foundation of the Madain Saleh (al Ghabban et al. 2011, 66).

The voice of traditional Muslim historiography takes the lead in the following "Pre-Islamic Era" exhibition hall. On the information board, the origin of Ka'ba is explained through al-Bakarah's verse 127 and alHajj's verse 26. Moreover, the hall's guidebook underlines the idolatry and polytheistic religions of this epoch from the traditional historiography's perspective:

The god to whom be ascribed all perfection and majesty created the man as a monotheist for his god and worshiper to him naturally, but with the passing of time he goes far from monotheism and subjacent with myths" and "it's being believed that, verily Arabs still on religion of Ibrahim AlKhalil (SAV) unto passing of two centuries on death of his son Ismail (SAV) then they started aberrancy towards myths and idolatry. (Al-Haffy 2007, $17,[$ sic $])$

These quotations recall the concept of fitra in Islam and explain why the pre-Islamic period is defined as al-jabiliyyah in the museum. This term, aljabiliyyah, is derived from the word jabl, which means ignorance and passion. This "ignorance," implied in the hall guide, is neither artistic nor technological one but religious. In both the National Museum and the local museums, elements of this period are not labeled except using the concept of ignorance (Michael Rice \& Company Ltd 1984; Zarins 1984). The complexity of settlements, markets, trade, and industry during the aljabiliyyah era is stressed comprehensively throughout the National Museum. Above all, al-jabiliyyah poetry is praised and considered a significant component of the Kingdom's heritage. For instance, a poetry recital competition was held in the "Al-Jahiliyyah Era" hall on February of 2015, during which female students from public and private elementary schools wore "pre-Islamic era costumes" and recited pre-Islamic poems 
about the architectural model of Okaz Market in the hall (The National Museum 2015). Can the term al-jahiliyyah be discussed as a terminus ante quem for a definition of an Islamic past? The ongoing academic debates on the meaning of al-jahiliyyah and the broader application of this term in the Muslim historiography prove that it is an analytically loose term (Fayda 1993, 17-19; Webb 2014, 91-93).

A wide range of connotations have been ascribed to al-jabiliyyah since the ninth century AD. Some of the hadith collections, the Qur'an commentaries, and classical Arabic texts associate al-jabiliyyah with individualized pre-Islamic pasts of the first generation of Muslims, the heroism and nobility of Arab tribes, and a moral state of being without any reference to a time period. Al-jabiliyyah became a paradigmatic element for defining barbarism and idolatry in the late sources and was used for defining a pre-Islamic past and, in some cases, an apocalyptic future (Webb 2014, 70-75). Saudi historiography demonstrates these various connotations explicitly. The takfirist approach in Saudi historiography views "the age of ignorance" as encompassing not only the pre-Islamic era, but the entire period prior to the rise of Salafism. ${ }^{3}$ On the other hand, some Saudi scholars, in particular al-Uthaymin and alAnsary, link the use of the term "pre-Islamic civilization" with "unification of the kingdom" in the narratives of the National Museum. According to Matthias Determann (2014, 124-128), this debate reverberated in the exhibition narratives of the National Museum through the mixture of the results of archaeological research with elements of traditional Muslim historiography.

Nonetheless, with its circular atrium and long corridor, the "Prophet's Mission" hall constitutes an architectural watershed in the primordial timeline of the museum. Various manuscripts of the Quran are on display in the heart of the circular atrium lighted with layers of bright colors. Duskily lit, this long corridor-decorated with ceramic murals featuring the Prophet's migration to Medina-directs visitors to the next hall, "Islam and the Arabian Peninsula." The polities that emerged in the peninsula after the death of the Prophet are represented in this hall. A significant point to note in this hall is that the Ottoman period is presented alongside those of the Umayyads, Abbasids, and Mamluks. Adducing from the contents of the National Museum guidebook and the hall's guide, it is safe to suggest that the Ottoman past is considered an epoch of the Islamic era in the peninsula by the SCTH (see al-Gahbban et al. 2011). This epoch is mainly described with references to the proliferation 
of Ottoman defensive architecture in the peninsula and the expansion of Ottoman control from Hejaz to al-Hasa.

The two halls that follow in the museum focus on the first and the second Saudi states and the Unification War, featuring some elements of both the takfirist and unionist approaches to history. The museum guidebook states that "the first Saudi state promoted the law of God and the Sunnah of his Messenger" against "the heresies and superstitions that were widespread in the Najd at that time" (al Ghabban et al. 2011, 33). Moreover, King Abdulaziz's expeditions to Southern Najd, al-Qassim, the Hejaz, the Eastern Province, the Asir, Ha'il, Jazzan, and Tihamanah between 1903 and 1930 were not interpreted as jihad or Islamic conquests but as a quest for unity and stability (Al-Eissa 2007, 4-20; Determann 2014, 127). Last, the "Gallery of Hajj and the Two Holy Mosques" extends the scope of the theme of unity and stability to the global scale, by pointing out the Saudi Kings' title: the Custodian of the Two Holy Mosques (Al-Hadlaq 2007).

To summarize, the narratives of the National Museum and the museums of Tayma and al-Ula illustrate a broader conceptualization of Islamic past and heritage beyond a particular period and geography. Indeed, this past mastering in enclosed spaces has national, global, and dynastic elements in it, but the religious historiography remains the overarching aspect (see Determann 2014). I argue that this overarching role and the Islamic perception of a primordial time problematizes the use of "Islamic" as a disciplinary qualifier, while defining tangible and intangible heritage institutionally nonetheless.

\section{The Hejaz Railway}

With a length of over $1,900 \mathrm{~km}$ extending from Damascus to Medina, the Hejaz Railway was one of the most ambitious projects of the late Ottoman Empire at the beginning of the twentieth century. As a new hajj route made of steel and well-cut stone structures, the Hejaz Railway weakened the role of camel caravans in the hajj. The construction of the main line was launched in 1900 and finished in 1908 (Çetin 2010, 100-102; Hulagü 2008). The additional lines were built up until 1918. Station buildings, military outposts, telegraph lines, trenches, rails, and water wells were painstakingly set on the formidable desert and mountainous landscape during this period.

The construction of the Railway was financed through numerous sources: credits from the Ottoman Agricultural Bank; the sale of 
transaction stamps; donations from Muslim, Christian, and Jewish Ottoman citizens; as well as voluntary salary cuts among government officials. In particular, donations from the international Muslim community were pivotal both in terms of project feasibility and the Pan-Islamic agenda of Sultan Abdulhamid II. Their donations covered the expenditure for one-third of the construction project (Çetin 2010, 103-117; Hulagü 2008, 118-122; Koloğlu 2017, 242). These donations were a result of a well-conducted Ottoman propaganda campaign targeting both the Ottoman population and the international Muslim community. The construction project was publicized as a great project that would ease the travel of pilgrims to Mecca and Medina and "beatify the soul of the prophet and overwhelm the World Muslim population's blessings" (Çetin 2010, 101). Moreover, it was also promoted as a national financial investment in distant parts of the Empire (Çetin 2010, 103-105).

The Ottoman Empire's propaganda was well received in most of its provinces and among the international Muslim community, but it failed miserably in the Hejaz. One of the major reasons of this failure was the militaristic potential of the line. The fast and efficient transportation of Ottoman troops to the Hejaz was posing a significant threat to the de facto autonomy of the local tribes. Moreover, there were also economic reasons behind the local upheaval: The construction of the line meant a substantial decrease in the hajj transportation revenues of the local inhabitants. The Ottoman officials tried to convince the local inhabitants that the Railway would open a new corridor of trade for their products, such as wool and leather. However, these promises did not have a major resonance among local populations (Ozyuksel 2014, 86-160; Koloğlu 2017, 237-238). With the revolt of Sharif Hussein against the Ottoman Empire in 1916, the Pan-Islamic image of the Railway faded away. The carriages were now carrying soldiers, equipment, and provisions to the Hejaz. Consequently, the train line fell under the administration of the Military Railways and Ports Directorate in 1917 (Çetin 2010, 113). As an irony of fate, the trains of the Hejaz Railway carried away the artifacts housed in alMasjid al-Nabawi (the Prophet's Mosque) to Istanbul during the siege of Medina in 1917. Nowadays, these artifacts constitute a substantial part of the "Sacred Relics Collection" of the Topkapı Palace (Bardakçi 2012; Nizamoglu 2013; Koloğlu 2017, 316).

Given its history, the Hejaz Railway could be viewed as Islamic heritage and an expression of faith, or as an expression of Ottoman control from Islamic archaeology's point of view. For my part, the 
Hejaz Railway is an exemplary case that shows how problematic it can be to label a site as Islamic or not: While the takfirist paradigm in Saudi historiography associates the Ottomans with the notion of al-jabiliyyah (Determann 2014, 28), the Hejaz Railway is related to Pan-Islamism by various Turkish scholars (Çetin 2010, 103-117). Beyond these dichotomies, the material remains of the Railway and its surroundings bear witness to varying perceptions about this piece of Ottoman past lying on Saudi soil. Among these structures, the Railway's stations in Mada'in Saleh, al-Ula, Medina, and Tabuk stand as sites that have been altered, utilized, redefined, and recreated by both the local populations and the post-Ottoman polities of the region from their time of construction up to the present. In the following sections, a selection of these activities will be addressed in order to provide insight on the formation processes of the Hejaz Railway's material culture as well as the changing views pertaining to it.

\section{Re-purposing an Ottoman Past}

Starting with the Mamluk campaign of Sultan Selim I in 1516-1517, Ottoman claims and rule in the Hejaz took form mainly through largescale construction projects. The Hejaz Railway was the final ring on a chain of imperial projects. In contrast with these imperial projects, rock art stands out as one of the major nonstate expressions of human presence in the Hejaz region. The walls of the Tabuk railway station and the rock faces in the surrounding landscape of the Railway have long been subjected to this form of art. The Tabuk station is not an isolated example: Graffiti and drawings have also been identified by the Great Arab Revolt Project team in Wadi Rum in Jordan (Saunders and Faulkner 2010, 520). Rock art is a centuriesold activity in Arabia, which can be traced back to the Iron Age through epigraphy, and according to some researchers, to the Neolithic, in respect to the arguable stylistic comparisons observed (Khan 1993, 2000, 13, 2007; Olsen 2013). However, the contemporary and the twentieth-century rock art examples have not been studied in depth. They are usually viewed as acts of vandalism by the SCTH, since most of the recorded examples were chipped or painted over earlier examples of rock art (see Alrawaibah 2013, 153). For my part, the vandalism theme is not explanatory in these cases since the older examples of rock art are usually applied on top of each other. The Tabuk station demonstrates a similar approach; a juxtaposition of state (station buildings) and nonstate (rock art) forms of expression. 
A closer look at three wall drawings on the office-lodge building of the Tabuk station sheds light on the possible motives behind their application on its walls. A geometrical figure on one of the window niches of the Tabuk station building shows some close similarities with the wusum (tribal brands; singular wasm) of the al-Hatarsha and al-Shararat tribes from northern Saudi Arabia (see Dickson 1967; Field 1952; Khan 2000, 16-75). This particular mark might have been chipped by a member of a sub-tribe or branches of these tribes, since an additional mark was applied on the upper right-hand side of the figure. Presently, wusum are mainly used to brand livestock and personal objects like knives, rugs, and tents by tribe members in order to mark their ownership of commodities. In addition, wusum are well-known features of the rock art sites, particularly in the vicinity of key ground features such as wells, seasonal water ponds, and camp sites. It is not unusual to find the wusum of tribes in places far from their base. This suggests they are also signifiers of tribal and perhaps personal presence in a particular location.

Given the current state of evidence, whether the wasm in the Tabuk station is a sign of a commodity or a sign of presence is not clear. What is clear, however, is that this wasm is an expression of a local identity that stands in contrast with both the Pan-Islamic plans of Abdulhamid II and the later Ottomanist goals of the Young Turks in the Hejaz (Makdisi 2002, 768-771; Rogan 1996, 83-86). It is important to outline that the Tabuk station and the other stations in these rural areas were constantly targeted by Bedouin groups. Consequently, the Ottoman authorities replied to these attacks by fortifying the stations and their surrounding landscape and arming their train carriages (Hulagü 2008, 130; Ozyuksel 2014, 156; Saunders and Faulkner 2010, 519). To this end, the Railway became a symbol of otherness and oppression in the eyes of some of the paramount tribes such as the Bani Harb and Bani Ali (Nicholson 2005, 44-46; Ozyuksel 2014, 153-156). The Railway meant more centralized Ottoman control over the local tribes on crucial matters such as arms trade, hajj income, water supply, taxation, and conscription (Hulagü 2008, 127-128; Ozyuksel 2014, 219-225).

It is not possible to conclude whether the figures were applied to the walls while the Tabuk station was in use. Only a figure of a palm tree between two crossed sabers beside a windowsill can be dated to a particular period, since it is the national emblem of the Kingdom of Saudi Arabia since 1950 (Central Department of Statistics and Information 2015; Determann 2014,9). In contrast with the wasm figure, the national 
emblem is one of the primary symbols of nation building in the presentday Saudi state, which emerged after a long war of unification between 1902 and 1932 (Al-Azzam et al. 2014, 31; Al-Simari 2012, 566; Leatherdale 1983, 37-45). An offshoot of the national emblem, such as the logo of SCTH, brings the unitarian intentions behind the national emblem to the forefront, representing how:

$[\mathrm{H}]$ armonious lines of the logo converge to form a palm tree (a sign of generosity and hospitality) and a pair of crossing swords demonstrates authority, tradition and heritage. Thus, the logo reflects the singularity and the brevity of an official institution of a modern vibrant Saudi Arabia. Saudi Arabia with its different social customs, heritage and popular cultures in its regions is represented in the logo with thirteen acute angles of a palm. In fact, there are thirteen regions in the Kingdom with attractive tourism activities that are rich and unique. (SCTH 2015)

Presently, the SCTH logo is used on the information boards in the Tabuk station museum and on the signboard of the SCTH Tabuk branch, which is currently based in one of the station buildings. By doing so, the Tabuk station is rebranded as part of a common Saudi heritage by the SCTH.

Not all figures on the Tabuk station's office-lodge building are signifiers of a national or a tribal identity; some are simply a form of self-expression through art. Roughly rendered animal figures underneath one of the windowsills is a good example. The torso and the face of the animal are rectangular in shape and its legs, ears, and tail are rendered as straight lines. Given how it is drawn, the figure shares same stylistic characteristics with various equine and dog figures in the rock art sites across the Kingdom (see Khan 1993, 2007; Olsen 2013). The different contexts of these figures, ranging from the Ottoman railway structure to the pre-historic rock art site of Jubbah, indicate that the notions of style and identity have little value in proposing a chronology or an ideological framework for these figures. Perhaps, then, the flat slab stone might simply have been a suitable "canvas" for the application of this animal representation.

\section{Utilizing and Refurbishing the Ottoman Past}

Beyond its ideological and historical significance, the Hejaz Railway can be viewed as a complex structure comprised of iron rails and well-cut stone structures. These material remains of the Railway were reutilized by the 
local population in various ways up to the recent past. These activities can be dated back to the construction of the line; for instance, in 1908, the Ottoman officials reported that a large number of wooden telegraph poles and crossties were dismantled by the Bedouins. In response, the scraped crossties had to be replaced with steel ones (Ozyuksel 2014, 153). After the disbandment of the line, utilization of the Railway's construction materials by the locals became more complex. Some of the stations, such as the al-Ula station, were transformed into new and more confined spaces. The station buildings were enclosed by a mud-brick wall. Moreover, the interior became occupied by a series of mud-brick structures that were incorporated into the station buildings.

Observing photographs taken during the 1907 opening ceremony and the 1917 Hejaz Expedition, it is safe to assume that these additions were built after the station lost its original function (see Bragger 2002). In contrast with the late Ottoman and early-twentieth-century German-style buildings of the al-Ula station, the mud-brick structures manifest local architectural traits, such as saw tooth parapets and narrow wall slits (see Albini 1998). However, the roofing of these mud-brick structures was not made with traditional construction materials, such as palm trunks, but rather with iron rails dismantled from the Railway. A similar case can also be observed in the center of al-Ula town, where stone and mud-brick houses display the use of metal rails as door and window niches during.

As a result of government and private sector enterprises and projects in Saudi heritage tourism in the last two decades, the Hejaz Railway stations found themselves in the limelight (Burns 2007; Al Ghabban 2012). The sites started to be viewed as a touristic and cultural asset of the Kingdom at the official level. Some of the stations, including Medina, Mada'in Saleh, and Tabuk, were restored and refurbished under the supervision of SCTH. The Mada'in Saleh station was organized as a visitor center at the entrance of the Nabataean site of al-Hijr, which became Saudi Arabia's first World Heritage site in 2008 (Alrawaibah 2013). The visitor center comprises an exhibition hall, coffee shop, a projection room, toilets, and a bookshop. The relatively large and rectangular train maintenance workshops of Mada'in Saleh, Tabuk, and Medina stations are currently being used as exhibition halls. The reason behind this choice is quite obvious: The railway in the middle of the structure allows for the display carriages and trains to be under a roof, while the raised platforms around the railway offer an area for the display of information boards and artifacts in a linear way. In the case of Madain Saleh station, one of the carriages was 
transformed into a small screening room in which a documentary about the history of the line can be seen, attracting children in particular. Unlike the other stations, the Tabuk station is currently being incorporated into a contemporary piece of architecture to house the Tabuk Archaeology Museum. The museum is positioned behind the station buildings, and it will provide a larger exhibition area relative to the train maintenance workshops.

This interest in the Hejaz Railway is not just circumscribed to the circles of the SCTH; it is also raised by a number of independent scholars with different backgrounds (al Faqeer 2009, 174-182; Burns 2007, 227; Orbasli and Woodward 2008). For instance, Aylin Orbasli and Simon Woodward surveyed the entire railway line in Saudi Arabia between 2001 and 2004. They viewed the Railway and its associated structures as a cultural route stimulating heritage tourism in the country. In 2008, they proposed that the Railway line has a great potential to be a linear heritage attraction and "the physical remains of the Railway can be used as an anchor for the preservation and interpretation of the Islamic and pre-Islamic cultural heritage of the route" (Orbasli and Woodward 2008, 159). Dr. Bader Bin Adel Al Faqeer, associate professor in the Geography Department at King Saud University, looked at the Hejaz Railway from a more localized standpoint. In particular, he tackled the relationship between the components of the railway in al-Ula province and its surrounding landscape, considering picturesque views that the garrisons, stations, and railway tracks could offer to future visitors (al Faqeer, Badr Bin Adel Bin Mohammad 2009, 311-319). In this work, he describes the Hejaz Railway as "one of the most important archaeological monuments in Al-Ula province" (al Faqeer, Badr Bin Adel Bin Mohammad 2009, 311). This "importance" is explained through inclusion of the Hejaz Railway on the United Nations Educational, Scientific, and Cultural Organization's (UNESCO) tentative list and the site's potential as "a religious, cultural and strategic heritage" (al Faqeer, Badr Bin Adel Bin Mohammad 2009, 311; UNESCO 2015).

\section{Exhibition and Revival of the Ottoman Past}

Leaving aside the architectural changes made in these stations, a closer look at the information boards in the exhibition halls of the Mada'in Saleh and Tabuk stations offers a glimpse of the present-day official interpretation of the Hejaz Railway. Generally speaking, the boards describe the architectural 
features and the history of the Railway using a technical and a descriptive tone. However, beyond a conventional historical description of the Railway, there was a patron behind the Hejaz Railway project-Sultan Abdulhamid II, a historical figure who remains controversial today. As a result of his relatively oppressive rule, isolated life style, informer network, bold projects, and global vision, the image of the sultan was a deeply polarizing one among his contemporaries, and continues to be so among present-day societies that once lived under Ottoman rule (see Sakaoglu 1999, 535538). The labels attested to him by both his opponents and his supporters best express this polarization: "The Red Sultan" (Roubille 1900, 1), "The Owl of the Yildız Palace" (Ersoy 1999, 361), "The Accursed" (Ersoy 1999, 114), and "The Supreme Khan" (Fazıl 2007, 1). The exhibition boards in the Tabuk and Madain Saleh stations feature Abdulhamid II from a more positive angle by pointing out his plans to revive and modernize the Empire by the means of railways and telegraph lines. Yet, there is no mention of his Pan-Islamic agenda or his political plans for the region.

Alongside the aforementioned restoration and refurbishment activities, the Hejaz Railway has recently become an inspiration for a revivalist trend in Saudi architecture. The visitor center of Dedan, the Lihyanite capital, clearly illustrates this impact. The building shows some traits of the guard outposts on the railway line: well-cut stone walls, a triple-arched porch, and slightly rectangular layout. Yet the contemporary Saudi architectural elements can also be seen on this structure: Windows are longer and rectangular in form and they are coated with green film. This revivalist piece of architecture and its function as the visitor center of a pre-seventh-century $\mathrm{AD}$ site highlights the density of meanings and labels that can be ascribed to the Hejaz Railway. In this section, I tried to categorize these labels through fieldwork and literary survey. What these labels show us is an ongoing reinterpretation process. The Railway moved from being a project to "beatify the soul of the prophet" in 1900 (Çetin 2010, 101) to being a linear heritage attraction for today's tourists (see Orbasli and Woodward 2008). This sharp difference clearly illustrates that there is no single adjective, including Islamic, that can be used to label this railway system.

\section{Conclusions}

The discussion in this article suggests that "Islamic heritage" can only be defined as a highly subjective and problematic term. The case studies of Saudi museums and the Hejaz Railway recall the title of 
this chapter-"framing the primordial." They indicate a number of potential drawbacks for any attempt to contextualize terms such as "Islamic archaeology," "Islamic heritage," or "Islamic past." Taking a side in debates about faith is one of these major drawbacks. Islamic archaeology and emerging critical studies in Islamic heritage usually approach the material culture of different cultural and religious movements among Muslim societies and individuals from a secular tradition. This approach might be effective at avoiding a situation where Islamic archaeology is wielded as tool for questioning the validity of these faiths. However, this secular stance also takes a side in these debates by gathering different expressions of faith under the "Islamic" adjective. The description of the pre-Saudi period as al-jabiliyyah in the takfirist Saudi historiography, as well as ever-changing official and local perceptions concerning the Hejaz Railway, express the fluidity of the term "Islamic heritage." This fluidity pinpoints the second potential bias: the overlooking of any sociopolitical or personal connotations behind examples of tangible heritage. The formation processes of the Hejaz Railway structures, and the nationalist, global, and dynastical elements in the Saudi museums' narratives, can generate different adjectives depending on the outlook.

This point leads us to the final drawback: the vulgarization and fetishization of the "Islamic" adjective by attesting a certain material culture and timeframe to it. Generally speaking, the relationship between Muslims and a pre-Islamic past is presented as a case of apathy (see Blau 1995, 122; Liverani 2005, 225; Potts 1998, 195-196). The ambiguity of Muslims to a pre-Islamic past is expressed through few and overly repeated examples: Ibn al-Kalbi, al-Maqrizi, and Abd alLatif's studies on the pre-Islamic past; revivalist demonstrations, like the 2,500 year celebration of the Persian Empire in 1971; and the admiration for al-Jahiliyyah poetry (see Hawting 1999, 2; Insoll 1999, 230; Milwright 2009, 5; Petersen 2014, 6269). The Saudi museums examined here suggest that a Muslim ambiguity to the pre-seventhcentury AD period is beyond the scope of these fragmentary examples and references, at least on an official level. These museums manifest a primordial timeline within the contexts of Islam, official historiography, and archaeological studies. Above all, these case studies indicate that there is a much broader understanding of the Islamic past in regard to the Muslim belief that Islam is the primordial faith (Hawting 1999, 21; Kuzgun 1997; Leaman 2006, 242). 


\section{Notes}

1. These sites were visited by the author in 2009, 2011, and 2014 .

2. This name was adopted in 2015. The previous name of the organization was the Saudi Commission for Tourism and Antiquities (SCTA).

3. Saudi chronicler Husayn Ibn Ghannām framed the "takfirist" paradigm (from takfir, "to announce someone an unbeliever"). This paradigm argues that only the supporters of Ibn Abd al-Wahhab's mission, led by the Al Saud, were true Muslims (Determann 2012, 47).

Acknowledgments The author would first like to thank Dr. Trinidad Rico for encouraging him to present this paper at the Islamic Pasts workshop and for commenting on various drafts. The author would also like to thank Dr. Matthias Determann and Dr. Jose Carvajal Lopez for reading drafts of this paper and making many useful criticisms. Many thanks to Dr. Cemal Omer, Dr. Arnulf Hausleiter, Prof. Robert Carter, Prof. David Wengrow, Prof. Thilo Rehren, Alaa Alrawaibah, and Samovar Sami for their support in my field investigations.

\section{BIBLIOGRAPHY}

Adang, Camilla. 2000. "Islam as the Inborn Religion of Mankind: The Concept of Fitra in the Works of Ibn Hamza." Al-Qantara: Revista de Estudias Árabes no. 21 (2): 390-409.

al Faqeer, Badr Bin Adel Bin Mohammad. 2009. Nature and Antiquities in AlUla Province/Saudi Arabia a Touristic Jewel. Riyadh, Saudi Arabia: King Fahd National Library.

Al Ghabban, Ali 2012. "Kingdom of Saudi Arabia and Its Heritage." In Roads of Arabia: Archaeology and History of Kingdom of Saudi Arabia, edited by Ali Al Ghabban, Béatrice André-Salvini, Françoise Demange, Carine Juvin, and M. Cotty, 35-39. Paris: Musée du Louvre.

al Ghabban, Ali, H.A. al-Hassan, al-Saud A., al-Ghazzi A., al-Salook M.A., alShammary J.B., al-Hadlaq A.S., al-Khalifa K., al-Badawi W., al-Hammad A., alBaqia N., and M Khan. 2011. The National Museum Guide. Riyadh, Saudi Arabia: Saudi Commission for Tourism and Antiquities.

Al-Azzam, B., M Al-Ahaydib, and M Shalaby 2014. "The Socio-Cultural, Historical, and Political Allusions in the Translation of the Saudi National Day Poetry: 'Peace, O Gracious King' as a Case Study." Studies in Literature and Language no. 9 (3): 30-39.

Albini, Marco. 1998. Traditional Architecture in Saudi Arabia: The Central Region. Riyadh, Saudi Arabia: Ministry of Education, Kingdom of Saudi Arabia. 
Al-Eissa, A.M. 2007. Gallery of Unification of the Kingdom. Riyadh, Saudi Arabia: National Museum.

Al-Hadlaq, A.S. 2007. Gallery of Hajj and the Two Holy Mosques. Riyadh, Saudi Arabia: National Museum.

Al-Haffy, M. 2007. Gallery of the Pre-Islamic Era. Riyadh, Saudi Arabia: National Museum.

Alrawaibah, Alaa. 2013. "Archaeological Site Management in the Kingdom of Saudi Arabia: Protection or Isolation." In Cultural Heritage in the Arabian Peninsula: Debates, Discourses, and Practices, edited by Karen Exell and Trinidad Rico, 143-156. Surrey, UK: Ashgate.

Al-Simari, F.A. 2012. "The Kingdom of Saudi Arabia." In Roads of Arabia: Archaeology and History of Kingdom of Saudi Arabia, edited by Ali Al Ghabban, Béatrice André-Salvini, Françoise Demange, Carine Juvin, and M. Cotty, 565-566. Paris: Musée du Louvre.

Bardakçi, Murat. Kutsal Emanetler'deki Hazineler, Bugün Fabreddin Pasa'nmn Sayesinde Bizdedir 2012 [accessed August 5, 2015]. Available from http:// www.haberturk.com/yazarlar/murat-bardakci/727818-kutsal-emanetlerdekihazineler-bugun-fahreddin-pasanin-sayesinde-bizdedir.

The Basic Law of Governance. Royal Embassy of Saudi Arabia, Washington, D.C. 1992 [accessed July 3, 2015]. Available from https://www.saudiembassy.net/ about/country-information/laws/The_Basic_Law_Of_Governance.aspx.

Blau, Soren. 1995. "Observing the Present-Reflecting the Past. Attitudes Towards Archaeology in the United Arab Emirates." Arabian Archaeology and Epigraphy no. 6 (2): 116-128.

Boddy, Trevor. 1999. "History's New Home in Riyadh." Saudi Aramco World no. 50 (5): 22-29.

Bragger, Roger. El Ula Station 2002 [accessed August 10, 2015]. Available from http://www.rogersstudy.co.uk/hejaz/hejaz_railway/el_ula_station.html.

Burns, Peter. 2007. "From Hajj to Hedonism? Paradoxes of Developing Tourism in Saudi Arabia." In Tourism in the Middle East: Continuity, Change, and Transformation, edited by Rami F. Daher, 215-236. Clevedon, UK: Channel View Publications.

Central Department of Statistics and Information. 2015. Facts about the Kingdom, Central Department of Statistics and Information. Saudi Arabia: Central Department of Statistics and Information [accessed July 14, 2015].

Çetin, Emrah. 2010. "Türk Basinina Göre Hicaz Demiryolu." History Studies, Middle East Special Issue: 99-115.

Commins, David. 2006. The Wabhabi Mission and Saudi Arabia. New York: Palgrave Macmillan.

Determann, Jörg Matthias. 2012. Globalization, the State and Narrative Plurality: Historiography in Saudi Arabia. Wusum. London: Department of History, School of Oriental and African Studies. 
Determann, Jörg Matthias. 2014. Historiography in Saudi Arabia: Globalization and the State in the Middle East. London: I.B. Tauris.

Dickson, Harold R.P. 1967. The Arab of the Desert. London: George Allen \& Unwin Ltd.

Ersoy, Mehmet A. 1999. Safahat. Edited by M. Ertugrul Düzdag. Istanbul: Sule Yayinlari.

Fayda, Mustafa. 1993. “Cahiliye." Türkiye Diyanet Vakfi Islam Ansiklopedisi no. 7, 14-19.

Fazil, Necip F. 2007. Ulu Hakan: Ikınci Abdülhamid Han. Istanbul: Büyük Dogu Yayınevi.

Field, Henry. 1952. "Camel Brands and Graffiti from Iraq, Syria, Jordan, Iran, and Arabia." Journal of The American Oriental Society, Supplement 15.

Grube, Ernst J. 1978. "What Is Islamic Architecture?" In Architecture of the Islamic World: Its History and Social Meaning, edited by George Mitchell, 10-15. New York: William Morrow and Company.

Hawting, Gerald R. 1999. The Idea of Idolatry and the Emergence of Islam: From Polemic to History. Cambridge: Cambridge University Press.

Hökelekli, Hayati. 1996. "F1trat.” Türkiye Diyanet Vakfi Islam Ansiklopedisi no. $13,47-48$.

Holtzman, Livnat. 2010. "Human Choice, Divine Guidance and the Fitra Tradition: The Use of Hadith in Theological Treatises by Ibn Taymiyya and Ibn Qayyim al-Jawziyya." In Ibn Taymiyya and His Times, edited by Yossef Rapoport and Shahab Ahmed, 163-189. Oxford: Oxford University Press.

Hulagü, Mehmet. 2008. Bir Umudun Insaasi: Hicaz Demiryolu. Izmir: Yitik Hazine Yayinevi.

Ibn Abd Al-Wahhab, Muhammad. 2010. Kitab al-Tawheed. Translated by Sameh Strauch. Riyadh, Saudi Arabia: International Islamic Publishing House.

Insoll, Timothy. 1999. The Archaeology of Islam. Oxford: Oxford University Press. Insoll, Timothy. 2007. "Changing Identities in The Arabian Gulf." In The Archaeology of Identities: A Reader, edited by Timothy Insoll, 309-321. London: Routledge.

Introduction, The National Museum. 2015 [accessed August 5, 2015]. Available from http://www.nationalmuseum.org.sa/introduction.aspx.

Khan, Majeed. 1993. Prehistoric Rock Art of Northern Saudi Arabia. Riyadh, Saudi Arabia: Department of Antiquities and Museums.

Khan, Majeed. 2000. Wusum: The Tribal Symbols of Saudi Arabia. Riyadh, Saudi Arabia: Ministry of Education, Deputy Ministry of Antiquities \& Museums.

Khan, Majeed. 2007. Rock Art of Saudi Arabia across Twelve Thousand Years. Riyadh, Saudi Arabia: Ministry of Education, Deputy Ministry of Antiquities \& Museums.

Koloğlu, Orhan. 2017. Türk-Arap Illişkileri Tarihi. Istanbul: Tarihçi Kitabevi. 
Kuzgun, Saban. 1997. "Hanif." Türkiye Diyanet Vakfi Islam Ansiklopedisi no. 16, 33-39.

Leaman, Oliver. 2006. The Qur'an: An Encyclopedia. London: Routledge.

Leatherdale, Clive. 1983. Britain and Saudi Arabia, 1925-1939: The Imperial Oasis. London: Frank Cass.

Liverani, Mario. 2005. "Imperialism." In Archaeologies of the Middle East: Critical Perspectives, edited by Susan Pollock and Reinhard Bernbeck, 223-244. Malden, MA: Blackwell Publishing.

Makdisi, Ussama. 2002. "Ottoman Orientalism.” The American Historical Review no. 107 (3): 768-796.

Milwright, Marcus. 2009. "Defining Islamic Archaeology-Some Preliminary Notes.” AKPIA@MIT Forum: Studies in Architecture, History, and Culture:1-11.

Milwright, Marcus. 2010. An Introduction to Islamic Archaeology. Edinburgh, UK: Edinburgh University Press.

Nehmé, Laila. 2007. “The Rediscovery of Madâ'in Sâlih, Ancient Hegra, Saudi Arabia." Bulletin of the Society for Arabian Studies no. 12, 11-13.

Nicholson, James. 2005. The Hejaz Railway. London: Stacey International.

Nizamoglu, Yüksel 2013. "1917 Yilinda Hicaz Cephesi: Arap Isyaninin Yayilmasi ve Medine'nin Tahliyesi Programi." Bilig 66, 123-148.

Noyes, James. 2013. The Politics of Iconoclasm: Religion, Violence, and the Culture of Image-Breaking in Christianity and Islam. New York: I.B. Tauris.

Okruhlik, Gwenn. 2004. "Over History and Identity: 'Opening the Gates' of the Kingdom to Tourism." In Counter-Narratives: History, Contemporary Society, and Politics in Saudi Arabia and Yemen, edited by Madawi Al-Rasheed and Robert Vitalis, 201-228. New York: Palgrave Macmillan.

Olsen, Sandra L. 2013. Stories in the Rocks: Exploring Saudi Arabian Rock Art. Pittsburgh, PA: Carnegie Museum of Natural History.

Orbasli, Aylin, and Simon Woodward 2008. "A Railway 'Route' as a Linear Heritage Attraction: The Hijaz Railway in the Kingdom of Saudi Arabia." Journal of Heritage Tourism no. 3 (3): 159-175.

Ozyuksel, Murat. 2014. The Hejaz Railway: Modernity, Industrialization, and Ottoman Decline. London: I.B. Tauris.

Petersen, Andrew. 1996. Dictionary of Islamic Architecture. New York: Routledge.

Petersen, Andrew. 2014. "Religion in Islamic Archaeology." In Encyclopedia of Global Archaeology, edited by Claire Smith, 6268-6276. New York: Springer.

Potts, Daniel T. 1998. "The Gulf Arab States and Their Archaeology." In Archaeology Under Fire: Nationalism, Politics and Heritage in the Eastern Mediterranean and Middle East, edited by Lynn Meskell, 189-199. New York: Routledge. 
Rice, Michael, and Company Ltd. 1984. Six Site Museums in the Kingdom of Saudi Arabia Part 2, Phase 1: Taima. Riyadh, Saudi Arabia: Department of Antiquities and Museums, Ministry of Education.

Rogan, Eugene L. 1996. “Aşiret Mektebi: Abdulhamid II's School for Tribes (1892-1907)." International Journal of Middle East Studies no. 28 (1): 83-107.

Roubille, Auguste. 1900. Abdul Hamid II, Le Sultan Rouge. Vol. n5 Lyon, France: Le Musée de Sires.

Sakaoglu, Necdet. 1999. Bu Mülkün Sultanlari. Istanbul: Oglak Yayincilik.

Saunders, Nicholas J., and Neil Faulkner 2010. "Fire on the Desert: Conflict Archaeology and the Great Arab Revolt in Jordan 1916-1918." Antiquity no. $84,514-527$.

SCTH. National Museum, Saudi Commission for Tourism and National Heritage 2011 [accessed July 31, 2015]. Available from https://www.scta.gov.sa/en/ Antiquities-Museums/pages/NationalMuseum.aspx.

SCTH. Museum Directory, Saudi Commission for Tourism and National Heritage 2014 [accessed August 2, 2015]. Available from https://www.scta.gov.sa/ en/Museums/Pages/MuseumDirectory.aspx.

SCTH. Our Logo, Saudi Commission for Tourism and National Heritage 2015 [accessed July 22, 2015]. Available from http://www.scta.gov.sa/en/ AboutSCTA/Pages/OurLogo.aspx.

The National Museum. Pre-Islamic Poems Recited by Young Creative Girls at The National Museum, Saudi Arabia. The National Museum, Saudi Arabia 2015 [accessed August 1, 2015]. Available from http://www.nationalmuseum.org. sa/LatestNews.aspx?id=229.

UNESCO. The Hejaz Railway. UNESCO 2015 [accessed August 1, 2015]. Available from http://whc.unesco.org/en/tentativelists/6026/.

Webb, Peter. 2014. “Al-Jāhiliyya: Uncertain Times of Uncertain Meanings.” Der Islam no. 91 (1): 69-94.

Yusuf, Ali A. 2000. The Holy Quran: Translation by Abdullah Yusuf Ali. Kent, UK: Wordsworth Classics of World Literature.

Zarins, Juris. 1984. “Al-Hofuf, Najran, Jizan, Al-Ula/Taima, Al-Jawf: The Stone Age to the Mid-1st Milleunnium BC." In Six Site Museums in the Kingdom of Saudi Arabia, Part 3 Research Papers, edited by Michael Rice and Company Limited, Riyadh: Department of Antiquities and Museums, Ministry of Education.

Ömer Can Aksoy is a PhD candidate at UCL, Qatar, and coordinator of the Battle of Aslihanlar Project in Turkey. His research interests include ancient warfare in the Arabian Peninsula, wayfinding in archaeological sites, visual communication design, modern conflict archaeology in Turkey, use-wear analysis of metal weaponry, and rock art of Saudi Arabia and Oman. 
Open Access This book is licensed under the terms of the Creative Commons Attribution 4.0 International License (http://creativecommons.org/licenses/ by $/ 4.0 /$ ), which permits use, sharing, adaptation, distribution and reproduction in any medium or format, as long as you give appropriate credit to the original author(s) and the source, provide a link to the Creative Commons license and indicate if changes were made.

The images or other third party material in this chapter are included in the chapter's Creative Commons license, unless indicated otherwise in a credit line to the material. If material is not included in the chapter's Creative Commons license and your intended use is not permitted by statutory regulation or exceeds the permitted use, you will need to obtain permission directly from the copyright holder. 